\title{
ECONOMICAL STUDY ON CONSUMER BEHAVIOR TOWARDS SOME FUNCTIONAL FOODS AND FACTORS AFFECT CONSUMPTION OF IT.
}

\author{
ALIA A. EL- GENDY and HUSSEIN M. A. EL- BERRY \\ Food Technology Research Institute, ARC, Giza, Egypt
}

(Manuscript received 23 June 2015)

\begin{abstract}
$\mathrm{T}$ his study was carried out on a sample of Egyptian consumers (300) in Giza governorate to investigate their behavior towards consumption of some functional foods, also this study aimed to investigate the effect of some factors that may affect consumption of this type of food. As for the sample under study according to gender, $53 \%$ of the sample are males and $47 \%$ are females. In regard to age, $9 \%$ of the total sample under study are under 20 years old, $20 \%$ lie between $20-40$ years and $15 \%$ are more than 60 years old. Results showed the effect of income, educational status, family size and gender on the awareness of the consumers under study toward consumption of this kind of foods. The results were certified statistically towards the item of income, educational, family size, age, and not certified towards of gender. Also, results showed that media (especially T.V) is considered the main source of information about functional foods especially for illiterate and those who read and write, meanwhile reading and health professionals are considered the main source of information for those graduated and post graduated class. Also, results showed that females are more aware by this kind of food comparing to males. Results illustrated that large stores are the main source of getting this kind of foods especially dairy products low calorie beverages and low calorie bakery products. So, this study recommend taking measures towards improving consumer awareness towards the nutritional and medical importance of this kind of food through different sources of information specially media and taking measure to avoid misleading propaganda. Also, conducting more studies in this field especially from the economic point of view.
\end{abstract}

\section{INTRODUCTION}

The functional foods concept was first developed in Japan in the 1980's when, faced with escalating health care costs, the Ministry of Health and Welfare initiated a regulatory system to approve certain foods with documented health benefits in hopes of improving the health of the nation's aging population. These foods, which are eligible to bear a special seal, are now recognized as Foods for Specified Health use (FOSHU). As of Specified 2001, 271 food products had been granted FOSHU status in Japan $^{(1)}$ 
The American Association (ADA) takes one of the most inclusive views. In a position statement issued in 1999, the ADA described functional foods as "any potentially healthful food or food ingredient that may provide a health benefit beyond the traditional nutrients it contains" and also made the following very important points:Functional foods may be whole, fortified, enriched, or enhanced foods.To have a beneficial effect on health, a functional food would have to be consumed as part of a varied diet on a regular basis, at effective levels.It's likely that all foods are functional at some physiological level ${ }^{(1)}$

Functional foods are similar in appearance to conventional foods; the former being consumed as part of the normal diet. In contrast to conventional foods, however, have demonstrated physiological benefits and can reduce the risk of chronic disease beyond basic nutritional functions, including maintenance of gut health. When food is being cooked or prepared using "scientific intelligence" with or without knowledge of how or why it is being used, the foods is called "functional food". Thus, functional food provides the body with the required amount of vitamins, fats, proteins, carbohydrates, etc., needed for its healthy survival. ${ }^{(2)}$

Consumer interest in the relationship between diet and health has increased the demand for information about functional foods. Factors fueling U.S. interest in these foods including the rapid advances in science and technology, increasing healthcare costs, changes in food laws affecting label and product claims, an aging population and rising interest in attaining wellness through diet, among others. ${ }^{(4)}$

According to IFIC consumer research, Americans name themedia, health professionals, and family and friends as theirtop sources of information about foods that can promotehealth. Credible scientific research indicates there are manyclinically proven and potential health benefits from foodcomponents. Claims on food packages are just one vehiclefor informing consumers about these diet and healthrelationships ${ }^{(3)}$

Functional Foods: Their role in disease prevention and health promotion In the United States, the functional foods category is not recognized legally. Irrespective of this, many organizations have proposed definitions for this new and emerging area of the food and nutrition sciences. The Institute of Medicine's Food and Nutrition Board (IOM/FNB, 1994) defined functional foods as "any food or food ingredient that may provide a health benefit beyond the traditional nutrients it contains." Healthconscious baby boomers have made functional foods the leading trend in the U.S. food industry (Meyer, 1998). Estimates, however, of the magnitude of this market vary significantly, as there is no consensus on what constitutes a functional food. Decision Resources, Inc. (Waltham, 1998) estimates the market value of functional 
foods at $\$ 28.9$ billion. More significant, perhaps, is the potential of functional foods to mitigate disease, promote health, and reduce health care costs. ${ }^{(4)}$

The status of food imperfection in Egypt is resulted from the decline of the average per capita of supplied food and the expectation of more decline in the future as a result of population increase, GDP decline, and the increase of theaged population, these facts caused the need of using food as medicine for protection and disease prevention. Therefore, the need proceeded for using functional foods ${ }^{(5)}$. So, this study aims to identify the functional foods from socio-economic point of view as new field of food studies.

\section{Source of data and Methods:}

To carry out this study a randomly sample was chosen for 300 consumers from Giza. A questionnaire was designed to cover two purposes, the first: concerned with the profile of the consumers under study and their behavior towards of consumption of functional foods and the second: concerned with determining the role of some factors (I.e. size of family, educational status of consumer and income,.....) that many affect the consumption of this type of food.

\section{Sample description and weight of different parameters.}

Table (1) shows the profile of the consumers under study. According to gender, $53 \%$ of the sample are males and $47 \%$ are females. In regards to age, $9 \%$ of the total number of the sample is under 20 years old, $20 \%$ lie between 20 - 40 years old, $56 \%$ lie between 40 -less than 60 years old and $15 \%$ are 60 years old and more.

As for educational status, $7 \%$ of sample under study are illiterate, $23 \%$ read and write, $51 \%$ secondary schools graduated and $19 \%$ graduated and post graduated.

In regard to family size, $35 \%$ of the sample less than 4 individual, $59 \%$ lies between 4 and less than 7 individual and $6 \%$ range between 7 and more. 
Table 1. Relative distribution of the sample according to some parameters.

\begin{tabular}{|c|c|c|}
\hline Item & Number & $\%$ \\
\hline \multicolumn{3}{|l|}{ Gender: } \\
\hline - male & 159 & 53 \\
\hline - female & 141 & 47 \\
\hline \multicolumn{3}{|l|}{ Age: } \\
\hline - Less than 20 year & 27 & 9 \\
\hline - 20 less than 40 year & 60 & 20 \\
\hline - 40 - less than 60 year & 168 & 56 \\
\hline-60 year and more than & 45 & 15 \\
\hline \multicolumn{3}{|l|}{ Educational status: } \\
\hline - $\quad$ Illiterate & 21 & 7 \\
\hline - $\quad$ Red and write & 69 & 23 \\
\hline - Secondary schools & 153 & 51 \\
\hline - Graduated and post graduated & 57 & 19 \\
\hline \multicolumn{3}{|l|}{ Family size: } \\
\hline - $\quad$ Less than 4 individual & 105 & 35 \\
\hline - $\quad 4$ - less than 7 individual & 177 & 59 \\
\hline - $\quad 7$ and more individual & 18 & 6 \\
\hline \multicolumn{3}{|l|}{ Average of family income: } \\
\hline - $\quad$ Less than 700 L.E/month & 39 & 13 \\
\hline - $\quad 700$ - 1400 L.E/month & 141 & 47 \\
\hline - $\quad 1400$ and more/month & 120 & 40 \\
\hline
\end{tabular}

Source: data of the questionnaire.

As for average family income, $13 \%$ of the sample was less than 700 L.E/month, 47\% range between 700 - 1400 L.E/month and 40\% more than 1400 L.E/month.

\section{RESULTS AND DISCUSSION}

Results of table (2) shows that $58.7 \%$ of the consumer under study being aware of benefits of functional foods, and among $52 \%$ of them consumeit in spite they did not know its benefits. As for reasons why those don't consumer it $55 \%$ of them said that it is highly price, $25 \%$ of themcannot believe its benefits and $20 \%$ said that it is not available in the stores near for them. 
As for the source of knowledge, results shows that media is the main source of information about functional food their ratio reach $30.3 \%$ and $15.3 \%, 13 \%$ for friends and other sources respectively.

Table 2. Relative distribution of the sample according to some parameters.

\begin{tabular}{|l|c|c|}
\hline Item & Number & $\%$ \\
\hline Consumption & 156 & 52 \\
\hline Reasons of didn't buying it: & 11 & \\
Highly price & 5 & 25 \\
Unbelieving its benefits & 4 & 20 \\
Not available & 176 & 58.7 \\
\hline Awareness & & \\
\hline Source of Information: & 91 & 30.3 \\
Media. & 46 & 15.3 \\
Friends. & 39 & 13.1 \\
Others* & & \\
\hline
\end{tabular}

Source: data of the questionnaire.

\section{*education, Reading, Work, health professional and perfumer shop.}

To study consumer behavior towards consumption of some functional foods, the study classify this kind of food under three major categories, dairy products, bakery products and low calories beverages and drinks.

Table (3) illustrate the relative distribution of the sample according to the type of the consumed food and sources to get. In related to dairy products, $33 \%$ of the consumers consume low salt cheese, $26 \%$ of them consume light yogurt, followed by rayeb, zero milk and karish cheese, and their ratio reach $17 \%, 14 \%$ and $11 \%$ respectively. Also, the same table shows that the main source of buying these products is supermarkets. As for bakery products the same table shows that $17 \%$ of the sample under study consume brain bread and $88 \%$ buy it from supermarkets while $12 \%$ of them buy it from bakeries. As for other types of low call bakery products (i.e cake, tost,.....), $17 \%$ of the sample consume the type and $76 \%$ of them buy it from supermarkets. 
Table 3. Relative distribution of the sample according to performance of consumers towards type of product and source of getting it.

\begin{tabular}{|c|c|c|c|c|c|c|}
\hline \multirow{3}{*}{ Product } & \multicolumn{3}{|c|}{ consumers aware its benefits } & \multicolumn{3}{|c|}{$\begin{array}{c}\text { consumersdidn't aware } \\
\text { ofitsbenefits }\end{array}$} \\
\hline & \multirow[b]{2}{*}{$\%$} & \multicolumn{2}{|c|}{ Source } & \multirow{2}{*}{$\%$} & \multicolumn{2}{|c|}{ Source } \\
\hline & & $\begin{array}{l}\text { Super } \\
\text { market }\end{array}$ & others & & Super market & Others \\
\hline Dairy products: & 33 & 92 & 8 & 23 & 97 & 3 \\
\hline Low salt cheese & 26 & 100 & 0 & 0 & 0 & 0 \\
\hline Lignt rogurt & 17 & 85 & 15 & 15 & 100 & 0 \\
\hline Nayed & 14 & 100 & 0 & 7 & 100 & 0 \\
\hline Kharish cheese & 11 & 77 & 123 & 23 & 77 & 123 \\
\hline Bakery products: & & & & & & \\
\hline Brain bread. & 17 & 88 & 12 & 21 & 90 & 10 \\
\hline Low calories bakeryproducts. & 17 & 76 & 24 & 12 & 83 & 17 \\
\hline
\end{tabular}

Source: data of the questionnaire.

In relation to beverages table (4) shows that $23 \%$ of the consumers consume green tea, $21 \%$ low calories drinks, $11 \%$ others (Artemisia chamomile, fennel, mint, marjoram ) and $6 \%$ consumeLow calorie drinks.

The same table shows that most of the consumers asking low calories beverages and drinks and green tea prefer supermarkets, in case of some herbs (i.e. Artemisia chamomile, Fennel, Mint, Marjoram), the consumer prefer to buy it from others sources(i.e. spicey store and pharmacy).

Table 4. Relative distribution of the sample according to behavior of consumers towards type of product and source of getting it.

\begin{tabular}{|c|c|c|c|c|c|c|c|c|}
\hline \multirow{3}{*}{ Product } & \multicolumn{4}{|c|}{ consumers aware its benefits } & \multicolumn{4}{|c|}{$\begin{array}{c}\text { consumersdidn't aware of } \\
\text { itsbenefits }\end{array}$} \\
\hline & \multirow[b]{2}{*}{$\%$} & \multicolumn{3}{|c|}{ Source } & \multirow[b]{2}{*}{$\%$} & \multicolumn{3}{|c|}{ Source } \\
\hline & & $\begin{array}{c}\text { Super } \\
\text { market }\end{array}$ & $\begin{array}{l}\text { spicey } \\
\text { store }\end{array}$ & $\begin{array}{c}\text { Pharm } \\
\text { acy }\end{array}$ & & $\begin{array}{l}\text { Super } \\
\text { market }\end{array}$ & $\begin{array}{l}\text { spicey } \\
\text { store }\end{array}$ & $\begin{array}{l}\text { Phar } \\
\text { macy }\end{array}$ \\
\hline Beverages: & & & & & & & & \\
\hline Green tea & 23 & 57 & 26 & 17 & 20 & 46 & 54 & 0 \\
\hline Low calorie beverages & 21 & 100 & 0 & 0 & 14 & 100 & 0 & 0 \\
\hline Herbs & 13 & 40 & 33 & 27 & 9 & 38 & 12 & 50 \\
\hline Others* & 11 & 38 & 49 & 13 & 8 & 36 & 35 & 29 \\
\hline Low calorie drinks & 6 & 100 & 0 & 0 & 14 & 100 & 0 & 0 \\
\hline
\end{tabular}

Source: data of the questionnaire.

*Artemisia chamomile, Fennel, Mint, Marjoram. 


\section{Some factors affecting awareness and consumption of functional foods:}

First: Education status: Results of table (5) show that graduated and post graduated come in the first rank followed by secondary schools, then illiterate and at last those who read and write with a percentage $61 \%, 58.6 \%, 50 \%$ and $42.5 \%$ for each of them respectively, and the $\mathrm{q}^{2}$ value reach 4.49and this certified statistically at level 0.05. Also, it was illustrated that those graduated and post graduated are the more consumption for this type of food followed by those who read and write then those of secondary schools and at last come the illiterate in the last rank with a percentage $69.9 \%, 62.5 \%, 42.9 \%$ and $20 \%$ for each of them respectively, $q^{2}$ value reach 13.4 and this certified statistically at level 0.01 .

Second : age: The results of same table (5) show that the class of 60 years old and is the most class who aware of this type of food and its ratio reach of $69.2 \%$, and this followed by those of 40 - less than 60 years old and its ratio reach $65 \%$, followed by those of the rank 20- less than 40 years old with ratio $60 \%$ and at last those of less than 20 years old with a ratio reached $29.2 \%$ and value of $q^{2}$ reach 10.6 and this certified statistically at ratio 0.01 . As for the relationship between consumption and age, the results shows that the elder (i.e 60 and more ) are the most consumption class for consumption of functional foods ( with a ratio $57.4 \%$ ), followed by the class ranged from 40 - less than 60 years old ( with a ratio $51.8 \%$ ) followed by the class ranged from 20 - less than 40 and its ratio reached $30 \%$ and those of less than 20 years old and its ratio reach $16.7 \%$ and value of $\mathrm{q}^{2}$ reach 8.83 and the model was statistically certified at significant level 0.05 .

Table 5. Relative distribution of the sample according to some factors that affect awareness and buying of functional foods.

\begin{tabular}{|c|c|c|c|c|c|}
\hline \multirow[b]{2}{*}{ Item } & \multicolumn{4}{|c|}{ Educational Status } & \multirow[b]{2}{*}{ q2 } \\
\hline & Illiterate & $\begin{array}{l}\text { Read and } \\
\text { write }\end{array}$ & $\begin{array}{c}\text { Secondary } \\
\text { school }\end{array}$ & $\begin{array}{l}\text { Graduated and post } \\
\text { graduated }\end{array}$ & \\
\hline Aware & $50 \%$ & $42.5 \%$ & 58.6 & $61 \%$ & 4.79* \\
\hline \multirow[t]{2}{*}{ Consumption } & $20 \%$ & $62.9 \%$ & $42.9 \%$ & $67.9 \%$ & $13.4 * *$ \\
\hline & \multicolumn{5}{|c|}{ Age Status } \\
\hline Item & $\begin{array}{l}\text { Less than } 20 \\
\text { year }\end{array}$ & $\begin{array}{c}20 \text { less than } \\
40 \text { year }\end{array}$ & $40-60$ year & More than 60 year & $\mathrm{q} 2$ \\
\hline Aware & $29.2 \%$ & $60 \%$ & $65.1 \%$ & 69.2 & $10.6 * *$ \\
\hline \multirow[t]{2}{*}{ consumption } & $16.7 \%$ & $30 \%$ & $51.8 \%$ & 57.4 & $8.83 *$ \\
\hline & \multicolumn{5}{|c|}{ Income classes } \\
\hline Item & $\begin{array}{c}\text { Less than } 700 \\
\text { L.E/month }\end{array}$ & $700-14 c$ & ..E/month & $\begin{array}{c}\text { More than } 1400 \\
\text { L.E/month }\end{array}$ & $\mathrm{q} 2$ \\
\hline Aware & $55 \%$ & & & $85.6 \%$ & 1.4 \\
\hline \multirow[t]{2}{*}{ consumption } & $41.5 \%$ & & & $45 \%$ & $4.5^{*}$ \\
\hline & \multicolumn{5}{|c|}{ Family size } \\
\hline Item & $\begin{array}{c}\text { Less than } 3 \\
\text { person }\end{array}$ & 4: & erson & More than 7 person & $\mathrm{q} 2$ \\
\hline Aware & 58.9 & & & 61.5 & $7.5 *$ \\
\hline \multirow[t]{2}{*}{ consumption } & 53.6 & & & 56 & 0.52 \\
\hline & \multicolumn{5}{|c|}{ Gender } \\
\hline Item & \multicolumn{2}{|c|}{ Male } & \multicolumn{2}{|r|}{ Female } & $\mathrm{q} 2$ \\
\hline Aware & \multirow{2}{*}{\multicolumn{2}{|c|}{$\begin{array}{l}57.9 \% \\
47.3 \% \\
\end{array}$}} & & $59.5 \%$ & 0.4 \\
\hline consumption & & & & $54.1 \%$ & 0.7 \\
\hline
\end{tabular}

*: Signification at level $0.05 \% \quad * *$ : Signification at level $0.01 \%$

Source: data of the questionnaire. 
Third: Income level: Results of table (5) shows that those of income level more than 1400 L.E/ month come in the first rank in related to awareness of this type of food, followed by those of monthly income lie between 700 L.E and less than 1400 L.E and at last those of monthly income less than 700 L.E, but this model not certified statistically. As for consumption, results showed that those of high levels of income are the most consumers (its ratio reached $45 \%$ ), followed by those income level 700 less than 1400 L.E/month and at last those of monthly income less than 700 L.E. and the model was certified significantly at level 0.05 .

Fourth: Family size: Results of table (5) shows that those families of large size come in the first rank in related to awarenessand consumption of this type of food(awareness reach $61.5 \%$ and consumption reach $56 \%$ ) and follow it those of small size (awareness reach $58.9 \%$ and consumption 53.65) and this model didn't certificated statistically.

Fifth: Gender: Results shows that females were more aware and the more consumers for functional foods, their ratio reaches $59.5 \%$ for awareness and $54.1 \%$ for consumption. Meanwhile these ratio reach $57.9 \%$ and $47.8 \%$ respectively for men.

Table 6. source of information's and its effect on different classes of education.

\begin{tabular}{|l|l|l|l|l|}
\hline \multirow{2}{*}{ Education classes } & \multicolumn{4}{l}{ Source of information } \\
\cline { 2 - 5 } & T.V & Friends & spicey store & Others* \\
\hline Illiterate & 22 & 15.7 & 1 & 0.7 \\
Read and Write & 42.9 & 24.8 & 2 & 2.4 \\
Secondary School & 38.2 & 12.7 & 1.2 & 11.8 \\
Graduated and post graduated & 18 & 7.9 & 1.1 & 31.5 \\
\hline
\end{tabular}

Source: data of the questionnaire.

*education, Reading, Work, health professional and spicey store shop.

Results of this table shows that the main source of informations about functional foods is T.V followed by friends, followed by spicey store and education, reading, Work and health professionals come in the last rank.

Also this table shows that T.Vrepresent the first source of information specially for illiterate and those who read and write, meanwhile, reading and health professionals are the main source for graduated and post graduated class. 


\section{REFERENCES}

1. Averlija Cencic and Walter Chingwaru: "The Role of Functional Foods, Nutraceuticals, and Food Supplements in Intestinal Health" Nutrients 2010, 2, 611, 625; doi: 10.3390/nu2060611.

2. Facts About "Functional foods" A Report by the American council on Science and Health. URL:http://www.acsh.org.

3. Functional Foods, International Food Information, Council Foundation, http://foodinsight.org.

4. Functional Foods: Their Role in Disease Prevention and Health Promotion A Publication of the Institute of Food Technologists Expert Panel on Food Safety and Nutrition Claire M. Hasler, Ph.D.

5 - عقيلة عز الدين طه (دكتور)، إقتصاديات البحوث و النطوير في مجال الغذاء، دراسة مسحية

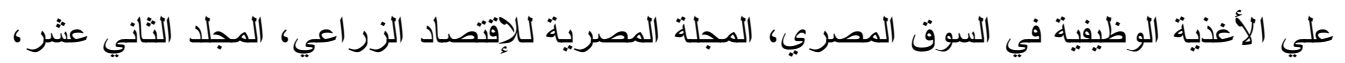
العدد الر ابع، ديسمبر الاعثه لوفيهه 2002. 


\section{دراسة إقتصادية لسلوك المستهلك تجاه بعض الأغذية الوظيفية و أهم العو امل المؤثرة علي إستهلاكها علية علي الجندي و حسين محمد أحمد البري معهُ بحوث تكنولوجيا الأغذية - مركز البحوث الزراعية - الجيزة - مصر}

هدف هذا البحث إلي التعرف علي سلوك المستهلك تجاه بعض الأغذية الوظيفية، ومدى معرفته بأهميتها، وكذا دراسة بعض العو امل التي قد تؤثز علي مدى وعي وإستهلاك هذا النوع من الأغذية

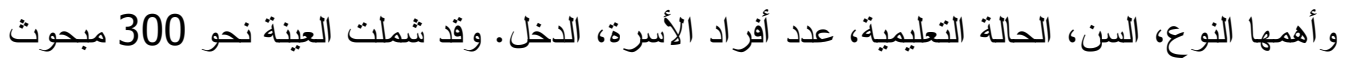

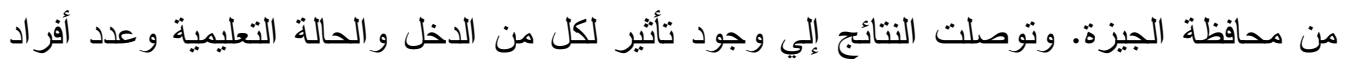

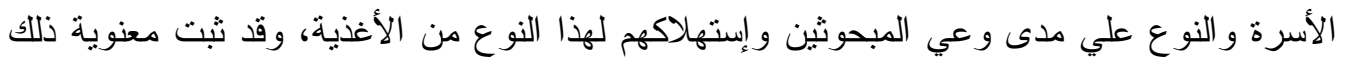

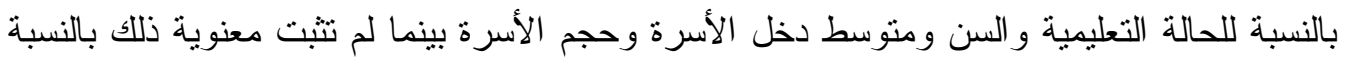

أيضا أثتبت النتائج أن وسائل الإعلام وخاصة التلفاز يعتبر المصدر الرئيسي للتعريف بالأغذية الوظيفية خاصة للفئة الأميه و الفئات التي تقر اء وتكتب، بينما كان الإطلاع و المختصين هم المصدر بعلئر الاساسي للتعريف بالمنتجات موضوع البحث وذللك بالنسبة للفئات الحاصلة علي درجات جامعية فأكثر ـ كما بينت نتائج البحث أن الإناث هم أكثر وعيا وإستهلاكا لتألك الأغذية مقارنة بالذكور . كما أثتتت النتائج أن أهم مصدر للحصول علي هذه المنت المنتجات كانت محلات البقالة الكبيرة (السوبر ماركت) و المستودعات، وكانت أهم هذه المنتجات هي الألبان و الجبن و المشروبات منخفضة السعرات ومنتجات المخابز منخفضة السعرات. وتوصي نتائج البحث بأهمية إجراء المزيد من ونين البحوث و الدراسات خاصة من الناحية الإقتصادية وذللك لندرة البحوث و الدراسات في هذا المجال، مع ضرورة العمل علي رفع وعي المستهلكين بأهمية هذه الأغذية سواء من الناحية الغذائية أو الو

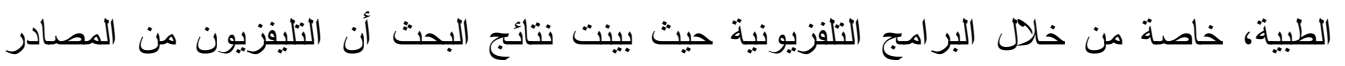

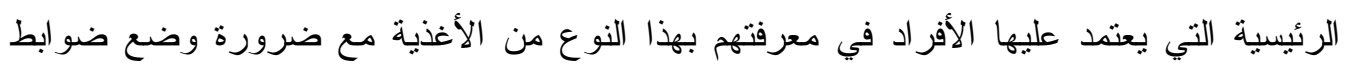
قانونية صارمة علي وسائل الإعلان المختلفة التي تستخدم للترويج لتسويق هذه الأغذية. 